\title{
Early thrombolysis in an elderly patient: case report
}

\author{
M Delle Curti, A Ciao, S Di Costanzo, B Lettieri ${ }^{*}$ \\ From XXIII Annual Meeting of the Italian Society of Geriatric Surgery \\ Lecce, Italy. 2-4 December 2010
}

\section{Background}

Pulmonary thromboembolism (TEP) is related to the migration of thrombotic material from the systemic venous circulation to pulmonary vascular tree, with obstruction of the pulmonary arterial circulation.

The mortality rate is $30 \%$ in non-identifiable forms, and $2-8 \%$ in those treated earlier.

The early use of thrombolytics determines the success of the lysis. Thrombolysis is considered a proven treatment in the management of acute, massive forms of TEP that accompany a hemodynamic instability, but differences arise over time, the doses and which thrombolytic use, to minimize the adverse events in compromised patients. Adverse events are: major bleeding, strokes, severe hypotension, allergies, re-thrombosis and reperfusion syndrome.

Contraindications are: absolute (internal bleeding in progress, recent spontaneous intracranial hemorrhage) and relative (interventions Chir. $<10$ days, stroke $<2 \mathrm{~m}$., Gastric bleeding $<10$ days, Major trauma $<15$ days, Recent CPR, PTL $<100,000$, poorly controlled severe hypertension, pregnancy).

\section{Case report}

Vincenzo R. 71 years-old, Kg110, is hospitalized for endoscopic pneumatic lithotripsy for an upper right ureter calculosis.

U.S. the lower limbs: thrombosis of the twin vein medial.

The maneuver, in general anesthesia, extends for 90'. At the awakening, after extubation occurs suddenly, dyspnea, pallor, precordial oppression. The ECG shows: FA with high ventricular response (160 bpm). There is also: PAs to $60 \mathrm{mmHg}$, SpO2 (65\%), moist raTes at bases,

\footnotetext{
* Correspondence: biagio.lettieri@unina2.it

Department of Anaesthesia, Surgical and Emergency Science, Second University of Naples, Italy
}

(ㄷ) 2011 Delle Curti et al; licensee BioMed Central Ltd. This is an open access article distributed under the terms of the Creative Commons Attribution License (http://creativecommons.org/licenses/by/2.0), which permits unrestricted use, distribution, and reproduction in any medium, provided the original work is properly cited. cyanosis. The blood gas analysis performed on the patient is reported in Fig 1, chest X-rays show a subtotal haziness of both hemithorax by interstitial edema and alveolar perfusion and a scintigraphy performed at 5 hours from the event supports the clinical suspicion of high probability for TEPM in place. D-dimer $>500 \mu \mathrm{g}$ / 1 confirmed the diagnosis. There are criteria for thrombolysis practice which lack the absolute and relative contraindications. After baseline control of coagulogramma we decide to give rtPA in less time than the traditional protocol (90' vs 120') with $40 \mathrm{mg}$ iv bolus within $15^{\prime}$ with an additional $60 \mathrm{mg}$ infusion in $250 \mathrm{ml}$ $\mathrm{NaCl} 0,9 \%$ for 80 '. The fall of the PTL and FDP are considered tolerable, bleeding seems to be minimal. On the

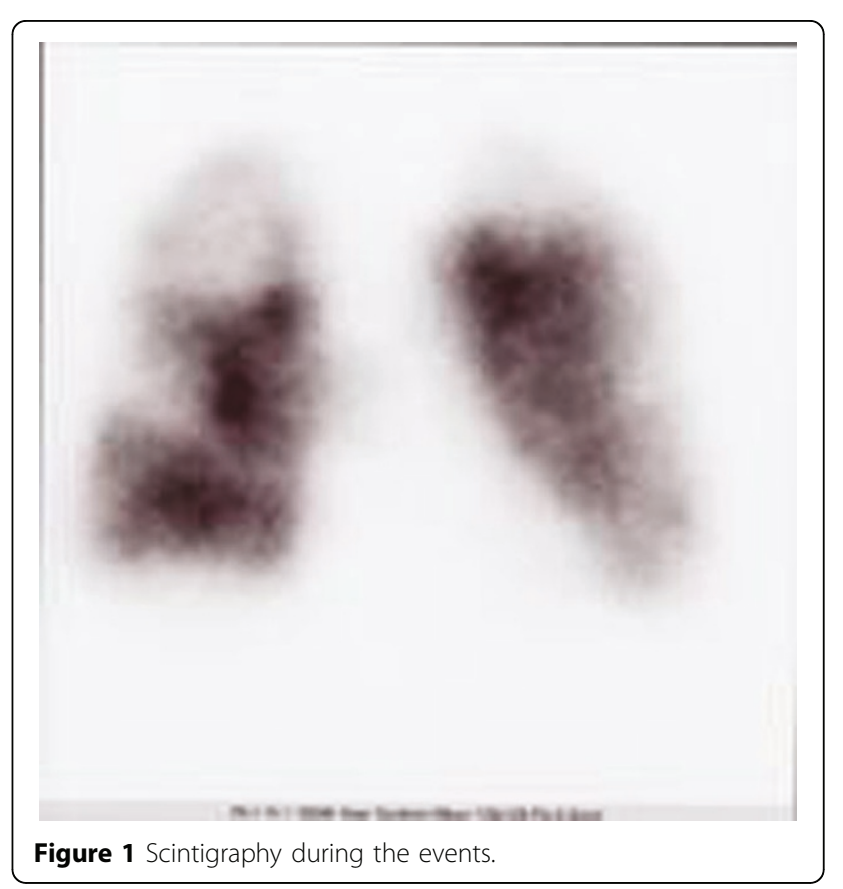




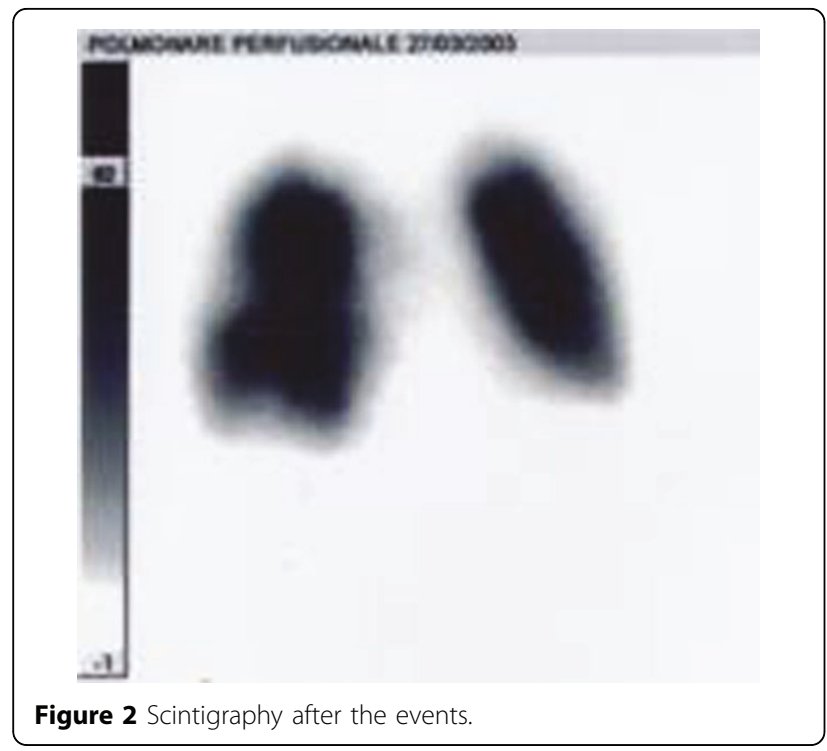

Valori Gas Ematici

$? \mathrm{pH}$

7.438

$\mathrm{PCO}_{2}$

$\mathrm{pO}_{2}$

$31.7 \quad \mathrm{mmHg}$

$68.3 \mathrm{mmH}$

Valori Ossimetrici

$\begin{array}{lrl}c t+H b & 11.9 & \mathrm{~g} / \mathrm{dL} \\ \mathrm{sO}_{2} & 93.9 & \% \\ F \mathrm{O}_{2} \mathrm{Hb} & 92.3 & \% \\ F \mathrm{COHb} & 1.2 & \% \\ F \mathrm{HHb} & 8.0 & \% \\ F M e t \mathrm{Hb} & 0.5 & \%\end{array}$

Valori Elettroliti

$\begin{array}{lrl}c K^{*} & 3.7 & \text { meqh } \\ c \mathrm{Na}^{*} & 136 & \mathrm{meq} h \\ c \mathrm{Ca}^{2} & 4.21 & \mathrm{mg} / \mathrm{d} \\ c \mathrm{Cl} & 102 & \mathrm{meq} / \mathrm{h}\end{array}$

Valori Metaboliti

$\begin{array}{rrr}\text { cGlu } & 120 & \mathrm{mg} / \mathrm{dL} \\ \text { cLac } & 5 & \mathrm{mg} / \mathrm{dL}\end{array}$

Valori Corretti con la Temperatura

$\begin{array}{crr}? \mathrm{pH}(T) & 7.438 & \\ \mathrm{PCO}_{2}(T) & 31.7 & \mathrm{mmHg} \\ \mathrm{DO}_{2}(T) & 88.3 & \mathrm{mmHg}\end{array}$

Stato di Ossigenazione
$\mathrm{CtO}_{x}$
$? \rho \mathrm{SO}_{\mathrm{c}}$
15.5 Vol\%
$25.52 \mathrm{mmHg}$

Stato Acido Base

$$
\begin{aligned}
& ? \text { cBase(Ecf) } 6 \\
& ? \mathrm{cHCO}_{3}-(\mathrm{P}, \mathrm{st})_{\mathrm{c}}
\end{aligned}
$$

\section{Valori Gas Ematici}

$\mathrm{pH}$

$\mathrm{NO}_{2}$

$\mathrm{pO}$

7.222

$55.1 \mathrm{mmHg}$

$51.9 \mathrm{mmHa}$

\section{Valori Ossimetrici}

cthib

$\mathrm{sO}_{2}$

$\mathrm{FO}, \mathrm{Ho}$

$F \mathrm{COHb}$

Fritib

FMetho

$18,0 \quad g^{\prime} d \mathrm{~L}$

$78.1 \%$

$77.5 \%$

$0.2 \%$

\begin{tabular}{|c|c|}
\hline $\mathrm{ck}^{*}$ & 4,0 \\
\hline $\mathrm{CNo}^{*}$ & 131 \\
\hline$\cdot \mathrm{Ca}^{24}$ & 4.28 \\
\hline${ }_{C \mathrm{Cl}}$ & 104 \\
\hline
\end{tabular}

$21.7 \%$

$0,6 \%$

Valori Elettroliti

\section{Valorı Metaboliti}

$\begin{array}{rrr}c \text { cGiu } & 182 & \mathrm{mg} / \mathrm{dL} \\ \mathrm{clac} & 10 & \mathrm{mg} / \mathrm{dL}\end{array}$

Vabri Corretti con la Temperatura

$\begin{array}{lrr}\mathrm{pH}(T) & 7.222 & \\ \mathrm{PCC}_{2}(T) & 55.1 & \mathrm{mmHg} \\ \mathrm{pO}_{3}\langle T\rangle & 51,9 & \mathrm{mmHg}\end{array}$

Stato di Ossigenazione

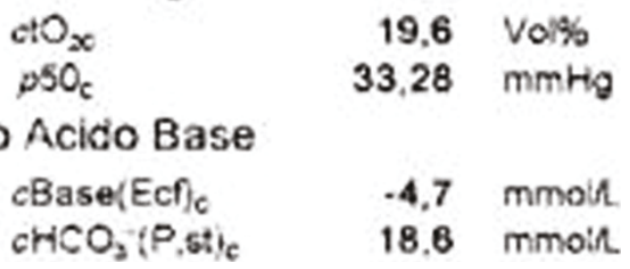

Figure $\mathbf{4}$ emogasanalysis after three days

third day we look at weaning with good spontaneous respiratory activity.

\section{Conclusions}

The case report is characterized by the presence of the most frequent risk factors for TEP, DVT, obesity, and by clear indications for thrombolysis: severe hemodynamic instability, the absence of contraindication, early diagnosis and therapy $(<8 \mathrm{~h})$. This allowed the procedure to obtain a good recovery accelerated thrombolysis and clinical scintigraphy without major bleeding complications.

Figure $\mathbf{3}$ emogasanalysis during the events 


\section{References}

1. Russo A: Invasive treatment of pulmonary embolism. G Chir 2009, 30(4):177-86.

2. De Roeck A, Hendriks JM, Delrue F, Lauwers $P$, Van Schil P, De

Maeseneer M, François O, Parizel P, d'Archambeau O: Long-term results of primary stenting for long and complex iliac artery occlusions. Acta Chir Belg 2006, 106(2):187-92.

3. Lankeit M, Konstantinides S: Mortality risk assessment and the role of thrombolysis in pulmonary embolism. Clin Chest Med 2010, 31(4):759-69.

4. Zhang NF, Zhou YM, Yang XY, Tang CL, Wu H, Zhong NS: Clinical characteristics and prognostic factors of pulmonary embolism in different age groups. Zhonghua Jie He He Hu Xi Za Zhi 2010, 33(6):436-40.

5. Jiménez D, Aujesky D, Yusen RD: Risk stratification of normotensive patients with acute symptomatic pulmonary embolism. Br I Haematol 2010, 151(5):415-24.

doi:10.1186/1471-2318-11-S1-A8

Cite this article as: Delle Curti et al.: Early thrombolysis in an elderly patient: case report. BMC Geriatrics 2011 11(Suppl 1):A8.

\section{Submit your next manuscript to BioMed Central} and take full advantage of:

- Convenient online submission

- Thorough peer review

- No space constraints or color figure charges

- Immediate publication on acceptance

- Inclusion in PubMed, CAS, Scopus and Google Scholar

- Research which is freely available for redistribution

Submit your manuscript at www.biomedcentral.com/submit 